\title{
Effect of thyme (T. vulgaris) extracts on fattening performance, some blood parameters, oxidative stress and DNA damage in Japanese quails
}

\author{
T. Sengül ${ }^{1,4}$, S. Yurtseven${ }^{1}$, M. Cetin ${ }^{1}$, A. Kocyigit ${ }^{2}$ and B. Sögüt ${ }^{3}$ \\ Harran University, \\ ${ }^{1}$ Agriculture Faculty, Department of Animal Science, \\ ${ }^{2}$ Faculty of Medicine, Department of Biochemistry \\ 63200 Sanliurfa, Turkey \\ ${ }^{3} Y \ddot{z} z \ddot{n}$ cü Yll University, Agriculture Faculty, Department of Animal Science \\ 65300 Van, Turkey
}

(Received 26 November 2007; revised version 9 July 2008; accepted 27 October 2008)

\begin{abstract}
The study was conducted to determine the effects of supplemented thyme oil extract and thyme water extract, the water soluble fraction of thyme extract, on fattening performance, blood parameters, oxidative stress and DNA damage in Japanese quails. Two hundred sixteen chicks were divided into four groups: control (no antibiotic or thyme extracts (I), flavomycin (II), thyme oil extract (III) and thyme water extract (IV). Groups II and III received $1 \mathrm{~g} / \mathrm{kg}$ flavomycin as an antibiotic and $2.5 \mathrm{ml} / \mathrm{kg}$ thyme oil extract, respectively. Birds in group IV received $100 \mathrm{ml} / 1$ of thyme water extract in their drinking water. There were no significant differences in liveweight between the treatment groups, but feed intake differed $(\mathrm{P}<0.01)$ at $0-5$ weeks of age. Results showed that thyme extracts decreased feed consumption during the experiment. Similarly, the survival rate differed significantly $(\mathrm{P}<0.01)$ between groups; the lowest was in antibiotic group. The levels of plasma cholesterol, triglyceride, high density lipoprotein, very low density lipoprotein and alkaline phosphates were similar in the four treatments. The highest rate of total oxidant status and total antioxidant response were found in group III, the lowest rate of DNA damage in the thyme oil (III) and thyme water extracts (IV) groups. It was concluded that supplementing thyme extract products in the diet of quails at the doses studied does not lead to a negative effect on the growth performance of the birds. Supplemented antibiotic caused an elevation in the oxidative stress index and in DNA damage.
\end{abstract}

KEY WORDS: quail, thyme extract, growth performance, antioxidant properties, DNA damage

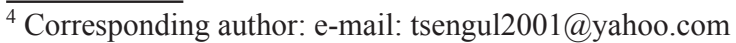




\section{INTRODUCTION}

As anti-microbial growth promoters (flavomycine, avilamycine, salinomycine, avoparcin, bacitracin, virginamycine, etc.), antibiotics have played a significant role in greatly increasing world poultry meat production. However, due to their side effects and the increased resistance of pathogen microorganism resulting from their use, antibiotic application has been restricted. Humans also receive exposure to antibiotic residues when consuming poultry products (Tajick and Shohreh, 2006). For these reasons, some poultry producers have voluntarily removed most or all of the antibiotics from their chicken feeds. Additionally, food safety has become an issue of greater public concern as part of the greater interest in healthy nutrition. The some growth promoter antibiotics (glycopeptide avoparcin, bacitracin, the macrolides, spiramycin, tylosin, streptogramin and virginiamycin) were withdrawn as growth promoters in the European Union between 1995 and 1999 on the basis of the Precautionary Principle. European Union has tightly regulated the use of antibiotics in chicken diets and antibiotics are restricted in the diets as growth promoter. These regulations have forced breeders to find alternatives to antibiotics. Some plants, containing various essential oils, have been used as alternative remedies by some researchers (Ceylan et al., 2003). Some studies have indicated that various plant extracts can improve feed conversion ratio (FCR), increase carcass quality and decrease the mortality rate (Parlat et al., 2005).

Thyme (T. vulgaris) is a plant that possesses antioxidants (Seung-Joo et al., 2004). The products of thyme extraction are thyme oil extract which contain approximately $15 \%$ essential oil (soluble in alcohol) and the thyme water extract (soluble in water). Essential oil is also extracted from fresh or partially dried flowering tops and the leaves of the plant by water or steam distillation providing a yield of $1.0 \%$ (Evans et al., 2001). The compounds which comprise the essential oil of T. vulgaris have been identified as phenoylic compounds such as tymol (44.4-58.1\%), carvacrol (2.4-4.2\%) and $\gamma$-terpipene (6.9-18.9\%). These compounds have strong antibacterial effects (Baranauskiene et al., 2003) and are also found in the extracted water soluble fraction of thyme.

Free radicals, which damage nucleic acids (DNA), are produced in metabolic and physiology processes, and harmful oxidative reactions may occur in organisms due to exposure to intensive stress. Additionally, some non-organic material can be a source of free radicals, such as herbicide, pesticide, solvents, drugs, petrochemical products, medicines and some food substances. It is also well known that some antibiotics used in animal diets damage DNA (Ferrazzi et al., 1991). Damage to DNA results changes to the genetic code which in turn causes abnormal cell death (Floyd, 1990), early aging and the proliferation of cancerous cells. Thymol 
is the antioxidant component in thyme (Aydin et al., 2005). By consisting of $\mathrm{OH}$, it functions as an " $\mathrm{H}$ " transmitter to peroxide after the oxidation of lipids, and through this alleviates the formation of the free radical hydroxyperoxide $\left(\mathrm{H}_{2} \mathrm{O}_{2}\right)$ (Lee et al., 2004). It has been reported that the essential oil extracted from thyme, and in particular the phenolic components (carvacrol and thymol), are responsible for the antioxidant activity observed in the lipid system (Deighton et al., 1993). Carvacrol kills pathogenic microorganism by disintegrating their cytoplasms, and also prevents an increase in plasma triglyceride and cholesterol (Lee et al., 2003). The goal of the present study was to examine the effects of thyme oil extract and thyme water extract on the fattening performance, survival rate, some blood parameters, oxidative stress and DNA damage in Japanese quail. The study also examined the degree of damage to DNA in blood cells caused by flavomycine.

\section{MATERIAL AND METHODS}

\section{Experimental diets and birds}

Dried thyme was ground in a knife mill to a particle size of 1-3 mm, and was separated into size fractions using sieves. A hydroalcoholic extract was prepared using food grade ethanol (96\%) and deionized water. The mixture was placed in a sealed glass vial in a heated water bath shaker for extraction. After extraction the glass vial was removed and left to cool for $10 \mathrm{~min}$. The mixture was vacuum filtered and the solid residue and hydroalcoholic extract collected. Evaporation of the hydroalcoholic solvent under reduced pressure gave an extract of $15 \%$ dry thyme containing $1.0 \%$ essential oil. Thyme water extract had also high ratio of essential oil (0.5-3.5\%) and was purchased from a commercial pharmaceutical shop in this region.

The experiment used 216 Japanese quail (Coturnix coturnix Japonica). The birds were divided into 4 groups $(n=54)$, each replicated (cages) three times with 18 birds per cage. The experiment lasted for 5 weeks. Chicks were reared in a brooder from 1 to 7 days old, and then placed in the cages. The light program consisted of $23.5 \mathrm{~h}$ light until 7 days of life and from then on $18 \mathrm{~h}$ light: $6 \mathrm{~h}$ dark. Birds were fed ad libitum with non-pelletted treatment diets during the experiment. The feed formulation and calculated analysis are presented in Table 1.

The control groups (I) was fed a basal diet with no antibiotic or thyme extracts. Groups II and III received the basal diet $+1 \mathrm{~g} / \mathrm{kg}$ flavomycin or $2.5 \mathrm{ml} / \mathrm{kg}$ thyme oil extract, respectively. The treatment diets were prepared by adding pre-diluted thyme extract or flavomycin to the basal experimental diet. Group IV received $100 \mathrm{ml} / 1$ extracted water of thyme in the drinking water. Antibiotics were not 
Table 1. Quail feed formulation and calculated analysis in experimental diets

\begin{tabular}{|c|c|c|c|c|c|c|c|c|}
\hline \multirow[t]{2}{*}{ Groups } & \multicolumn{2}{|c|}{$\begin{array}{c}\text { Control } \\
\text { I }\end{array}$} & \multicolumn{2}{|c|}{$\begin{array}{c}\text { Flavomycin } \\
\text { II }\end{array}$} & \multicolumn{2}{|c|}{$\begin{array}{l}\text { Thyme oil } \\
\text { extract } \\
\text { III }\end{array}$} & \multicolumn{2}{|c|}{$\begin{array}{c}\text { Thyme water } \\
\text { extract } \\
\text { IV }\end{array}$} \\
\hline & 0 to 3 & 4 to 5 & 0 to 3 & 4 to 5 & 0 to 3 & 4 to 5 & 0 to 3 & 4 to 5 \\
\hline \multicolumn{9}{|l|}{ Ingredients } \\
\hline maize, $\mathrm{g} / \mathrm{kg}$ & 380 & 450 & 380 & 450 & 380 & 450 & 380 & 450 \\
\hline wheat, $g / \mathrm{kg}$ & 130 & 150 & 130 & 150 & 130 & 150 & 130 & 150 \\
\hline soyabean meal $(47 \%), \mathrm{g} / \mathrm{kg}$ & 268 & 208 & 268 & 208 & 268 & 208 & 268 & 208 \\
\hline sunflower meal (35\%), g/kg & 100 & 100 & 100 & 100 & 100 & 100 & 100 & 100 \\
\hline fish meal $(65 \%), \mathrm{g} / \mathrm{kg}$ & 50 & 20 & 50 & 20 & 50 & 20 & 50 & 20 \\
\hline plant oil, $\mathrm{g} / \mathrm{kg}$ & 40 & 33 & 40 & 33 & 40 & 33 & 40 & 33 \\
\hline limestone, $\mathrm{g} / \mathrm{kg}$ & 7 & 8 & 7 & 8 & 7 & 8 & 7 & 8 \\
\hline dicalcium phosphate, $\mathrm{g} / \mathrm{kg}$ & 16 & 20 & 16 & 20 & 16 & 20 & 16 & 20 \\
\hline vitamin and mineral $\mathrm{mix}^{1}, \mathrm{~g} / \mathrm{kg}$ & 2.5 & 2.5 & 2.5 & 2.5 & 2.5 & 2.5 & 2.5 & 2.5 \\
\hline salt, $\mathrm{g} / \mathrm{kg}$ & 3.5 & 3.5 & 3.5 & 3.5 & 3.5 & 3.5 & 3.5 & 3.5 \\
\hline lysine, $\mathrm{g} / \mathrm{kg}$ & 0 & 1 & 0 & 1 & 0 & 1 & 0 & 1 \\
\hline dl-methionine, $\mathrm{g} / \mathrm{kg}$ & 1 & 1 & 1 & 1 & 1 & 1 & 1 & 1 \\
\hline anticoccidial, $\mathrm{g} / \mathrm{kg}$ & 1 & 1 & 1 & 1 & 1 & 1 & 1 & 1 \\
\hline flavomycin ${ }^{2}, \mathrm{~g} / \mathrm{kg}$ & -- & -- & 1 & 1 & -- & -- & -- & -- \\
\hline thyme oil extract, $\mathrm{ml} / \mathrm{kg}$ & -- & -- & -- & -- & 2.5 & 2.5 & -- & -- \\
\hline thyme water extract, $\mathrm{ml} / \mathrm{l}$ & -- & -- & -- & -- & -- & -- & 100 & 100 \\
\hline \multicolumn{9}{|l|}{ Calculated analysis } \\
\hline $\mathrm{CP}, \%$ & 24.0 & 20.0 & 24.0 & 20.0 & 24.0 & 20.0 & 24.0 & 20.0 \\
\hline $\mathrm{ME}, \mathrm{kcal} / \mathrm{kg}$ & 3000.0 & 3000.0 & 3000.0 & 3000.0 & 3000.0 & 3000.0 & 3000.0 & 3000.0 \\
\hline crude fibre, $\%$ & 4.43 & 4.37 & 4.43 & 4.37 & 4.43 & 4.37 & 4.43 & 4.37 \\
\hline ether extracts & 6.58 & 5.74 & 6.58 & 5.74 & 6.58 & 5.74 & 6.58 & 5.74 \\
\hline $\mathrm{Ca}, \%$ & 0.97 & 0.94 & 0.97 & 0.94 & 0.97 & 0.94 & 0.97 & 0.94 \\
\hline $\mathrm{P}, \%$ & 0.82 & 0.81 & 0.82 & 0.81 & 0.82 & 0.81 & 0.82 & 0.81 \\
\hline lysine, $\%$ & 1.36 & 1.15 & 1.36 & 1.15 & 1.36 & 1.15 & 1.36 & 1.15 \\
\hline methionine, $\%$ & 0.55 & 0.46 & 0.55 & 0.46 & 0.55 & 0.46 & 0.55 & 0.46 \\
\hline threonine, $\%$ & 0.83 & 0.72 & 0,83 & 0.72 & 0.83 & 0.72 & 0.83 & 0.72 \\
\hline tryptophan, \% & 0.28 & 0.24 & 0.28 & 0.24 & 0.28 & 0.24 & 0.28 & 0.24 \\
\hline
\end{tabular}

${ }^{1}$ contains per kg of diet, IU: vit. A 12.000 , vit. $\mathrm{D}_{3} 3.000$; mg: vit. E 35 , vit. $\mathrm{K}_{3} 5$, vit. $\mathrm{B}_{1} 3$, vit. $\mathrm{B}_{2}$ 6 , vit. $\mathrm{B}_{6} 5$, vit. $\mathrm{B}_{12} 30$, niacin 40 , d-pantothenic acid 10 , choline chloride 450 , folic acid 1 , biotin 75, Mn 80, Fe 40, Zn 60, Cu 5, I 5, Co 0.5, Se 0.15, antioxidant 10

2 flavomycin was not included in control, group III and IV rations. Group IV diet was same composition of control ration and this group was sustained thyme water extract with drinking water $(100 \mathrm{ml} / \mathrm{l})$

included in control and groups III and IV. However the standard mixture (group II) contained antibiotics. Chicks were weighed at the beginning of the experiment and assigned to treatment groups based on this weight. Subsequently, body weight 
(BW) and feed intake (FI) were recorded weekly. At the end of the trial, 6 birds from each replicate (total 72) were slaughtered and carcass weights determined. Blood samples were taken from the slaughtered birds and analysed.

\section{Blood sample preparation and analysis}

Blood samples were prepared to evaluate the extent of DNA damage and the some blood and oxidative parameters. After overnight fasting, peripheral blood samples (total $6 \mathrm{ml}$ ) were collected from the antecubital vein into heparinized tubes which were stored at $10{ }^{\circ} \mathrm{C}$ in the dark to prevent further DNA damage and processed within $2 \mathrm{~h}$.

Mononuclear leukocyte isolation for the comet assay was performed by use of Histopaque 1077 (Sigma). An amount of $1 \mathrm{ml}$ heparinized blood was carefully layered over $1 \mathrm{ml}$ hystopaque and centrifuged for $35 \mathrm{~min}$ at $500 \mathrm{~g}$ and $25^{\circ} \mathrm{C}$. The interface band containing mononuclear leukocytes was washed with phosphatebuffered saline (PBS) and then collected by a 15 -min centrifugation at $400 \mathrm{~g}$. The resulting pellets were re-suspended in PBS and the cells were counted in Neubaer Chamber. Membrane integrity was assayed by of trypan blue exclusion method. The remaining blood was centrifuged at $1500 \mathrm{~g}$ for $10 \mathrm{~min}$ to obtain the plasma. The separated plasma was then stored at $-80^{\circ} \mathrm{C}$ until further analysis of the other parameters and other oxidative stress parameters.

Mononuclear leukocyte DNA damage was analysed by alkaline comet assay according to Singh et al. (1988) with minor modifications. Ten microlitres of fresh mononuclear leukocyte cell suspension (around 20,000 cells) was mixed with $80 \mu \mathrm{l}$ of $0.7 \%$ low-melting-point agarose (LMA) (Sigma) in PBS at $37^{\circ} \mathrm{C}$. Subsequently, $80 \mu$ of this mixture was layered onto slides that had previously been coated with $1.0 \%$ hot $\left(60^{\circ} \mathrm{C}\right)$ normal melting point agarose (NMA) and covered with a coverslip at $4^{\circ} \mathrm{C}$ for at least 5 min to allow the agarose to solidify. After removing the coverslips, the slides were submersed in freshly prepared cold $\left(4^{\circ} \mathrm{C}\right)$ lysing solution (2.5 M NaCl, $100 \mathrm{mM}$ EDTA-2Na; $10 \mathrm{mM}$ Tris-HCl, $\mathrm{pH}$ 10-10.5; $1 \%$ Triton X-100; and 10\% DMSO added just before use) for at least $1 \mathrm{~h}$. Slides were then immersed in freshly prepared alkaline electrophoresis buffer $(0.3 \mathrm{~mol} / 1$ $\mathrm{NaOH}$ and $1 \mathrm{mmol} / \mathrm{l} \mathrm{Na} 2 \mathrm{ETDA}, \mathrm{pH}>13$ ) at $4^{\circ} \mathrm{C}$ for unwinding (40 min) and then electrophoresed ( $25 \mathrm{~V} / 300 \mathrm{~mA}, 25 \mathrm{~min})$. All steps were carried out under minimal illumination in order to prevent additional DNA damage. After electrophoresis, the slides were stained with ethidium bromide $(2 \mu / \mathrm{ml}$ in distilled; $70 \mu \mathrm{l} / \mathrm{slide})$, covered with a coverslip and analysed using a fluorescence microscope (Nikon, Japan) vided with epi-flourescence and equipped with rhodamine filter (excitation wavelength, $546 \mathrm{~nm}$; barrier filter, $580 \mathrm{~nm}$ ). The images of 100 randomly chosen nuclei (50 cells from each of two replicate slides) were analysed visually from 
each subject, as described elsewhere (Lampids et al., 2006). Each image was classified according to the intensity of the fluorescence in the comet tail and was given a value of either of $0,1,2,3$, or 4 (from undamaged class 0 to maximally damaged class 4), so that the total scores of slide could be between 0 and 400 arbitrary units (AU). All procedures were completed by the same biochemistry staff, and DNA damage was detected by a single observer who was not aware of subject's diagnosis.

Plasma lipid hydroperoxides (LOOH) were evaluated by an automated xylenol orange method based on that described by Jiang et al. (1991) in which $\mathrm{Fe}^{2+}$ is oxidized to $\mathrm{Fe}^{3+}$ by lipid hydroperoxides in an acidic medium. The values are presented in $\mu \mathrm{mol} / \mathrm{l}$.

The total anti-oxidative response (TAR) value of plasma was determined using a novel automated measurement method developed by Erel (2005). In this assay, a standardized solution of $\mathrm{Fe}^{2+}$-o-dianisidine complex reacts with a standard solution of hydrogen peroxide via a Fenton-type reaction, producing hydroxyl radicals. At a low $\mathrm{pH}$, this potent reactive oxygen oxidizes the reduced colourless o-dianisidine to yellow-brown coloured dianisidyl. The results are expressed as mmol Trolox equivalent/l.

Plasma Total oxidant status (TOS) levels were determined using a novel automated measurement method, developed by Erel (2005). In this method, oxidants present in the sample oxidize the ferrous ion-o-dianisidine complex to ferric ion. The oxidation reaction is enhanced by glycerol molecules, which are abundantly present in the reaction medium. The ferric ion makes a coloured complex with xylenol orange in an acidic medium. The colour intensity, which can be measured spectrophotometrically, is related to the total amount of oxidant molecules present in the sample. The assay is calibrated with hydrogen peroxide, and the results are expressed in terms of micromolar hydrogen peroxide equivalent per litre $\left(\mu \mathrm{mol} \quad \mathrm{H}_{2} \mathrm{O}_{2}\right.$ equiv/l).

The percent ratio of the TOS to the TAR gave the oxidative stress index (OSI), an indicator of the degree of oxidative stress (Erel, 2005). To perform the calculation, the result unit of TAS, mmol Trolox equivalent/l, was converted to $\mu \mathrm{mol}$ equivalent/l, and the OSI value was calculated as the formula:

$$
\text { OSI }=[(\text { TOS }, \mu \mathrm{mol} / 1) /(\text { TAR mmol trolox equivalent } / 1) \times 100] .
$$

The enzymatic activity of ceruloplasmin was measured according to Erel (1998) method. In this method, a ferrous ion is oxidized to ferric ions via ceruloplasmin ferroxidase activity. The amount of oxidized ion is related to the enzymatic activity and the values are presented in $\mu \mathrm{mol} / \mathrm{l}$.

Free sulphydryl groups (-SH) of serum samples were assayed according to the method of Ellman as modified by Hu et al. (1993). 
The levels of triglyceride (TG), total cholesterol (TC), HDL-cholesterol, LDLcholesterol, very low density lipoprotein (VLDL) and alkaline phosphates (ALP) were determined using commercially available assay kits with an Abbott Aeroset auto-analyzer (Abbott, Chicago, IL, USA).

\section{Statistical analysis}

Data were analysed by one-way analysis of variance $(\mathrm{P}<0.05)$ with a completely randomized design because there was no significant interaction observed between treatment groups and sex in terms of LW, LWG, FC and FCR. An Arc Sin transformation was required for the data on survival. Comparison of parameters was performed with the Duncan's multiple range test and data were analysed using the $\mathrm{SPSS}^{\circledR}$ for Windows computing program (Version 15.0, 2006).

\section{RESULTS}

Liveweight (LW), carcass weight, liveweight gain (LWG), feed consumption (FC), feed conversion ratio (FCR) and survival rate of quail during the experiment are presented in Table 2.

There were no significant differences in LW or LWG between the group means during the experiment. However, the mean FC differed between groups at $0-3$, 4-5 $(\mathrm{P}<0.05)$ and $0-5$ weeks of age $(\mathrm{P}<0.01)$. Although the FCR did not differ significantly when the experimental period was considered as a whole, that of group III (thyme oil extract) and IV (thyme water extract) tended to be better during weeks $0-3$ and 4-5. The FC of group III (thyme oil extract) was significantly lower than groups I (control), II (flavomycine) and IV during weeks 0-5 and the FC of group III (thyme oil extract) continued to be lower until the end of the trail $(\mathrm{P}<0.01)$. The mean carcass weights did not differ significantly between the treatments. The highest mortality rate was observed in group II (flavomycine), followed by the control group, whilst no birds died in groups III (thyme oil extract) and IV (thyme water extract).

According to the blood analyses, supplemented antibiotic, thyme oil extract and thyme water extract did not significantly affect concentration of triglyceride, total cholesterol, HDL-cholesterol, LDL-cholesterol and VLDL-cholesterol. The values of a selection of blood parameters from each treatment are presented in Table 3.

Significant differences in oxidative stress $(\mathrm{P}<0.01)$ were observed between the treatment groups (Table 4). 
Table 2. Production performance of experimental birds

\begin{tabular}{|c|c|c|c|c|c|c|c|}
\hline \multirow{2}{*}{ Item } & \multirow{2}{*}{ Sex } & \multicolumn{4}{|c|}{ Groups $^{1}$} & \multirow{2}{*}{$\mathrm{SEM}^{2}$} & \multirow{2}{*}{$\mathrm{P}$} \\
\hline & & I & II & III & IV & & \\
\hline \multicolumn{8}{|l|}{ Liveweight, $g$} \\
\hline \multirow{2}{*}{3 weeks } & M & 108.1 & 113.0 & 108.0 & 105.8 & 3.4 & NS \\
\hline & $\mathrm{F}$ & 109.1 & 114.4 & 111.8 & 113.6 & 3.2 & NS \\
\hline \multirow{2}{*}{5 weeks } & $\mathrm{M}$ & 150.7 & 152.8 & 151.1 & 147.6 & 4.8 & NS \\
\hline & $\mathrm{F}$ & 165.1 & 178.5 & 172.7 & 174.3 & 4.8 & NS \\
\hline \multirow{2}{*}{ Carcass weight, $g$} & M & 102.6 & 101.5 & 99.9 & 95.1 & 3.5 & NS \\
\hline & $\mathrm{F}$ & 104.6 & 105.1 & 111.0 & 106.1 & 3.6 & NS \\
\hline \multicolumn{8}{|l|}{ Liveweight gain, $g$} \\
\hline weeks $0-3$ & & 99.8 & 104.6 & 101.1 & 100.6 & 2.2 & NS \\
\hline weeks 4-5 & & 49.3 & 51.9 & 52.0 & 51.3 & 2.0 & NS \\
\hline weeks $0-5$ & & 149.1 & 156.6 & 153.1 & 151.9 & 3.2 & NS \\
\hline \multicolumn{8}{|c|}{ Feed consumption, $g$} \\
\hline weeks $0-3$ & & $244.8^{\mathrm{b}}$ & $260.7^{\mathrm{a}}$ & $231.1^{\mathrm{b}^{*}}$ & $242.5^{\mathrm{b}}$ & 5.0 & $*$ \\
\hline weeks 4-5 & & $289.3^{\mathrm{ab}}$ & $298.7^{\mathrm{a}}$ & $267.4^{b}$ & $282.1^{\mathrm{ab}}$ & 7.6 & $*$ \\
\hline weeks $0-5$ & & $534.2^{\mathrm{ab}}$ & $559.3^{\mathrm{a}}$ & $498.5^{\mathrm{c}}$ & $524.6^{\mathrm{bc}}$ & 10.6 & ** \\
\hline \multicolumn{8}{|l|}{$F C R, g: g$} \\
\hline weeks $0-3$ & & 2.5 & 2.5 & 2.3 & 2.4 & 0.1 & NS \\
\hline weeks 4-5 & & 6.3 & 6.2 & 5.4 & 5.8 & 0.4 & NS \\
\hline weeks $0-5$ & & 3.6 & 3.6 & 3.3 & 3.5 & 0.1 & NS \\
\hline \multicolumn{8}{|l|}{ Survival rate, \% } \\
\hline weeks $0-5$ & & $94.4^{\mathrm{b}}$ & $85.4^{\mathrm{a}}$ & $100.0^{\mathrm{b}}$ & $100.0^{\mathrm{b}}$ & 3.9 & $*$ \\
\hline
\end{tabular}

Table 3. Some blood parameter values in the four treatment groups ${ }^{1}$

\begin{tabular}{lccrrrr}
\hline Parameters, mg/dl & I & II & III & IV & SEM $^{2}$ & P \\
\hline Triglyceride & 225.8 & 195.8 & 184.4 & 175.0 & 29.9 & NS \\
Total cholesterol & 172.5 & 187.66 & 187.2 & 184.2 & 11.85 & $\mathrm{NS}$ \\
HDL-cholesterol & 115.8 & 128.0 & 116.7 & 122.1 & 9.47 & $\mathrm{NS}$ \\
LDL-cholesterol & 26.4 & 25.9 & 24.3 & 31.0 & 7.65 & $\mathrm{NS}$ \\
VLDL-cholesterol & 38.9 & 32.33 & 29.8 & 29.7 & 3.02 & $\mathrm{NS}$ \\
Alkaline phosphates (ALP) & 660.4 & 586.4 & 648.7 & 591.9 & 32.5 & $\mathrm{NS}$ \\
\hline
\end{tabular}

there were no significant differences among means within a row, NS - non-significant; ${ }^{1}$ the explanation see Table $2 ;{ }^{2}$ SEM - standard error of mean 
Table 4. Oxidative stress parameters and DNA damage in the four treatment groups ${ }^{1}$

\begin{tabular}{|c|c|c|c|c|c|c|}
\hline Parameters & I & II & III & IV & $\mathrm{SEM}^{2}$ & $\mathrm{P}$ \\
\hline Sulphydryl (SH), $\mu \mathrm{mol} / 1$ & 129.3 & 127.4 & 127.3 & 115.9 & 7.3 & NS \\
\hline Lipid hydroperoxides (LOOH), $\mu \mathrm{M}$ & 23.4 & 22.9 & 24.6 & 22.4 & 0.9 & NS \\
\hline Ceruloplasmin activity, $\mu \mathrm{mol} / 1$ & 375.3 & 452.1 & 470.0 & 460.0 & 61.4 & NS \\
\hline $\begin{array}{l}\text { Total antioxidant response (TAR), } \\
\mu \text { mol Trolox equiv./l }\end{array}$ & $175.11^{\mathrm{b}}$ & $102.1^{\mathrm{a}}$ & $244.73^{\mathrm{c}}$ & $185.0^{\mathrm{b}}$ & 19.4 & $* *$ \\
\hline $\begin{array}{l}\text { Total oxidant status (TOS), } \\
\quad \mu \mathrm{mol} \mathrm{H}_{2} \mathrm{O}_{2} / 1\end{array}$ & $23.3^{\mathrm{a}}$ & $21.4^{\mathrm{a}}$ & $29.7^{\mathrm{b}}$ & $24.6^{\mathrm{ab}}$ & 2.3 & $*$ \\
\hline Oxidative stress index (OSI) & $13.4^{\mathrm{a}}$ & $20.9^{b}$ & $12.3^{\mathrm{a}}$ & $14.0^{\mathrm{a}}$ & 1.07 & $* *$ \\
\hline $\begin{array}{l}\text { Mononuclear leukocyte } \\
\text { DNA damage (arbitrary units) }\end{array}$ & $11.27^{\mathrm{ab}}$ & $22.50^{\mathrm{b}}$ & $7.33^{\mathrm{a}}$ & $8.53^{\mathrm{a}}$ & 3.3 & $* *$ \\
\hline
\end{tabular}

a,b,c means within the same row with different common superscripts that differ significantly

${ }^{1}$ the explanation see Table $2 ;^{2} \mathrm{SEM}$ - standard error of mean, ${ }^{*} \mathrm{P}<0.05, * * \mathrm{P}<0.01$, NS - nonsignificant; OSI $=[($ TOS $\mu \mathrm{mol} / \mathrm{l}) /($ TAR mmol trolox equivalent/l $) \times 100]$

Treatment differences in sulphydryl values (SH), lipid hydroperoxide values $(\mathrm{LOOH})$ and ceruloplasmin activity were found to be non-significant. The highest total antioxidant response (TAR) was observed in group III (thyme oil extract) followed by groups IV (thyme water extract) and I (control), with the lowest TAR value being observed in the antibiotic group (group II). The total oxidant status (TOS) of group III (thyme oil extract) was significantly higher $(\mathrm{P}<0.05)$ than in the groups I and II. Lastly, the oxidative stress index (OSI) was highest in group II and lowest in group III, and, similarly, significant differences in DNA damage were observed between these groups $(\mathrm{P}<0.01)$. The most favourable result was found in the thyme oil extract group (Table 4, Figure 1).



Figure 1. DNA damage (arbitrary units) in the four treatment groups 


\section{DISCUSSION}

It is known that essential oils are used as feed supplements to improve growth performance under intensive systems (William and Losa, 2001). It was expected that supplementing extracted thyme oil and water would stimulate growth performance in the quail, but the influence on weight gain and FCR were not significant. Similar results have also been found in previous researches. Jang et al. (2006) failed to find a difference in body weight, feed intake or FCR between birds fed a basal diet and one supplemented with antibiotics or essential oil. In the current experiment, supplementation with thyme oil and extracted thyme water instead of antibiotic and control diet significantly lowered feed consumption. This may have resulted from the bitter taste of the phenolic compounds in thyme oil and water. However, Moran (1982) suggested that there was no significant correlation between dietary fat content and feed consumption in chickens, and speculated that chickens respond to the taste of feed less than other farm animals. In the present experiment, the use of higher doses of thyme extract than in other research (Parlat et al., 2005) and/or improvements in the digestibility of the extract could also explain the reduction in feed consumption in the experimental groups. Lee et al. (2003) reported that dietary thymol, and its isomer, carvacrol, lowered feed consumption in broilers. The authors speculated that supplementation with $100 \mathrm{ppm}$ of thymol stimulates the secretion of pancreatic enzymes, thereby improving FCR. In our experiment, the treatment groups consumed less feed and gained at a similar rate to the controls. In addition, similar results were observed for FCR, suggesting that thyme oil and water improved the digestibility of the feed. Parlat et al. (2005) indicated that supplementation with thyme oil resulted in a better FCR than controls and those supplemented with the antibiotic virginamycin. These results were taken as indicative that essential oils of plant origin stimulated enzymatic activity and improved the absorption of feed. Similarly, Sirvydis et al. (2003) reported that supplementation with plant extracts as a growth factor resulted in a greater impact on broiler performance than the administration of flavomycin. Parlat et al. (2005) also suggested that thyme essential oil had toxin binding effect and effectively diminished the detrimental effects of aflatoxin on performance.

The main compounds of thyme essential oil are thymol and its isomer, carvacrol. The compounds of the thyme oil and water were not seen a hypocholesterolaemic capacity. For example, Lee et al. (2003) found that thymol and carvacrol did not affect plasma cholesterol levels in either high or low cholesterol broilers. In our study, we also observed no significant difference between treatment groups in plasma cholesterol levels.

Oxygen products are produced by metabolic and physiological activity. Oxidative reactions may be damaging to the organism and the blood contains many 
antioxidants which scavenge harmful radicals. Thyme oil and water also possess antioxidants (Evans et al., 2001). The compounds of the thyme oil and water extract each have an antioxidant potential. In addition to both thyme oil and water extracts contain compounds (thymol, carvacrol, etc.) which are capable of participating in redox reactions (Kosar et al., 2005). In this study, an increased TOS value resulted in an increased TAR value in thyme oil and water treatment groups. This suggests that, due to the increased TAR in groups III and IV, the antioxidant compounds in thyme oil and water augmented the existing antioxidant systems. As the levels of thiol groups $(\mathrm{SH})$ and lipid hydroperoxides $(\mathrm{LOOH})$ did not differ between the groups, there was little evidence of oxidation of proteins and lipids. The diets of the groups did not include additional fat to absorb high levels of lipid (3-4\%).

Ceruloplasmin is an acute phase protein containing 7 copper atoms in plasma (Fox et al., 1995). It has been demonstrated that the pro-oxidative activity of ceruloplasmin is greatly enhanced under conditions of increased superoxide and other reactive oxygen species (Mukhopadhyay et al., 1996). Alkaline phosphates are also protein and liver enzymes (McPearson, 1996) whose plasma concentrations are increased during inflammation and damage to the liver. The activity of these parameters was not affected by thyme oil and water extract in comparison with the control and antibiotic groups.

The extent of DNA damage was found to be significantly lower in the thyme oil and water treated groups compared to the control and antibiotic groups $(\mathrm{P}<0.01)$. Aydin et al. (2005) observed similar results and concluded that it resulted from compounds in the thyme. Antibiotics act as growth factors by killing bacteria through inhibiting a bacterium's ability to turn glucose into energy, or its ability to construct its cell wall, but could also be harmful to host cells. The finding in the present study that high levels of DNA damage occurred in the antibiotic treated groups supports this. Aydin et al. (2005) reported that thymol and $\gamma$-terpipene $(0.1 \mathrm{mM})$ significantly reduced strand breakage in DNA induced by quinoline and mitomycin, and that carvacrol seemed to protect lymphocytes from the genotoxic effect of previous antibiotics at non-toxic concentrations below $0.05 \mathrm{mM}$. The finding of a lower TAR value in the antibiotic treatment indicates that the anti-oxidative defense system was weakened in these birds. However, the results suggest that oxidation was not the only cause of DNA damage in this treatment as the birds had a higher mortality rate. DNA damage appears to have originated primarily from oxidative stress but antibiotic supplementation also seems to have impaired the structural integrity of the cell. The existence of a higher mortality rate in the antibiotic treatment was probably due to the higher level of DNA damage, and consequently, the weakened self-defense system since, by the splitting DNA, cells are opened to mutation. Similarly several antibacterial antibiotics had been shown to participate with transition metal ions in chemical reactions leading to the formation of reactive oxygen species (Quinlan and 
Gutteridge, 1991). The decreased oxidative stress and DNA damage identified by this study as a result of supplementation with thyme oil and water is an important finding since, by aiding the antioxidant system of the body, the risk of developing cancer is likely to be reduced.

\section{CONCLUSIONS}

The present study showed that supplementation with thyme extracts as DNA damage detractive had a positive effect on quails. Although it is largely unknown how the phenolic and terpenic compounds of thyme oil protect against DNA damage, it is suggested that these compounds may act as free radical scavengers. Further studies on highly productive animals, especially under conditions of oxidative stress, would help to better establish the effects of thyme extract.

\section{REFERENCES}

Aydin S., Basaran A.A., Basaran N., 2005. The effects of thyme volatiles on the induction of DNA damage by the heterocyclic amine IQ and mitomycin C. Mutat. Res. 581, 43-53

Baranauskiene R., Venskutonis P.R., Viskelis P., Dambrauskiene E., 2003. Influence of nitrogen fertilizers on the yield and composition of thyme (Thymus vulgaris). J. Agr. Food Chem. 51, $7751-7758$

Ceylan N., Ciftci I., Ilhan Z., 2003. The effects of some alternative feed additives for antibiotic growth promoters on the performance and gut microflora of broiler chicks. Turk. J. Vet. Anim. Sci. $27,727-733$

Deighton N., Gidewell S.M., Deans S.G., Goodman B.A., 1993. Identification by EPR spectocroskopy of carvacrol and thymol as a major source of free radicals in the oxidation of plant essential oils. J. Sci. Food Agr. 63, 221-225

Erel O., 1998. Automated measurement of serum ferroxidase activity. Clin. Chem. 44, 2313-2319

Erel O., 2005. A new automated method to measure total antioxidant response against potent free radical reactions. Clin. Biochem. 37, 112-119

Evans J.W., Plunkett M.S., Banfieid M.J., 2001. Effect of essential oil blend on coccidiosis in broiler chicks. Poultry Sci. 80, Suppl. 1, 258 (Abstr.)

Ferrazzi E., Woynarowski J.M., Arakali A., Brenner D.E., Beerman T.A., 1991. DNA damage and cytotoxicity induced by metabolites of anthracycline antibiotics, doxorubicin and idarubicin. Cancer Commun. 3, 173-180

Floyd R., 1990. Role of oxygen free radicals in carcinogenesis and brain ischemia. FASEB J. 4, 2587-2597

Fox P.L., Mukhopadhyay C., Ehrenwald E., 1995. Structure, oxidant activity, and cardiovascular mechanisms of human ceruloplasmin. Life Sci. 56, 1749-1758

Hu M.L., Louie S., Cross C.E., Motchnik P., Halliwell B., 1993. Antioxidant protection against hyochlorous acid in human plasma. J. Lab. Clin. Med. 121, 257-262

Jang I.S., Ko Y.H., Kang S.Y., Lee C.Y., 2006. Effect of commercial essential oil on growth performance, digestive enzyme activity and intestinal microflora population in broiler chickens. Anim. Feed Sci. Tech. 134, 304-315 
Jiang Z.Y., Wollard A.C.S., Wolff S.P., 1991. Lipid hydroperoxide measurement by oxidation of $\mathrm{Fe}^{2+}$ in the presence of xylenol orange-comparison with the TBA assay and an iodometric method. Lipids 26, 853-856

Kosar M., Dorman H.J.D., Hiltunen R., 2005. Effect of an acid treatment on the phytochemical and antioxidant characteristics of extracts from selected Lamiaceae species. Food Chem. 91, 525-533

Lampids T.J., Kurtoglu M., Maher J.C., 2006. Efficacy of 2-halogen substituted D-glucose analogs in blocking glycolysis and killing "hypoxic tumor cells". Cancer Chemother. Pharmacol. 58, 725-34

Lee K.W., Everts H.J., Kappert H., Frehner R., Losa R., Beynen A.C., 2003. Effects of dietary essential oil components on growth peformance, digestive enzymes and lipid metabolism in female broiler chickens. Brit. Poultry Sci. 44, 450-457

Lee K.W., Everts H.J., Kappert H., Wouterse M.F., Beynen A.C., 2004. Cinnamanaldehyde but not thymol, counteracts the carboxymethyl cellulose-induced growth depression in female broiler chickens. Int. Poultry Sci. 3, 608-612

McPearson R.A., 1996. Clinical diagnosis and management by laboratory methods. In: J.B. Henry (Editor). Philadelphia, W.B. Saunders Company, pp. 237-257

Moran Jr. E.T., 1982. Comparative Nutrition of Fowl and Swine. The Gastrointestinal Systems. University of Guelph, Ontario (Canada)

Mukhopadhyay C.K., Ehrenwald E., Fox P.L., 1996. Ceruloplasmin enhances smooth muscle cell- and endothelial cell-mediated low density lipoprotein oxidation by superoxide-dependent mechanism. J. Biol. Chem. 271, 14773-14778

Parlat S.S., Yildiz A.O., Cufadar Y., Olgun O., 2005. Effects of thyme essential oil supplementation on performance of Japanese quail exposed to experimental aflatoxicosis. J. Agr. Faculty (Turkey) $19,1-6$

Quinlan G.J., Gutteridge J.M., 1991. DNA base damage by beta-lactam, tetracycline, bacitracin and rifamycin antibacterial antibiotics. Biochem. Pharmacol. 27, 1595-1599

Seung-Joo L., Katumi U., Takayuki S., Kwang-Geun L., 2005. Identification of volatile components in basil (Ocimum basilicum L.) and thyme leaves (Thymus vulgaris L.) and their antioxidant properties. Food Chem. 91, 131-137

Singh P.N., McCoy M.T., Tice R.R., Schneider E.L., 1988. A simple technique for quantitation of low levels of DNA damage in individual cells. Exp. Cell. Res. 175, 184-191

Sirvydis V.H., Bobiniene R., Priudokiene V., Vencius D., 2003. Phytobiotics add value to broiler feed. World Poultry 19,16-17

SPSS, 2006. Windows Evaluation Version (Base 15.0). Chicago, IL

Tajick M.A., Shohreh B., 2006. Detection of antibiotics residue in chicken meat using TLC. Int. Poultry Sci. 7, 611-612

William P., Losa R., 2001. The use of essential oils and their compounds in poultry nutrition. World Poultry 17, 1415 